\title{
Correction to: Presidents, Unified Government and Legislative Control
}

\author{
Jung-Hsiang Tsai
}

\section{Correction to:}

J.-H. Tsai (ed.), Presidents, Unified Government and Legislative Control, Palgrave Studies in Presidential Politics, https://doi.org/10.1007/978-3-030-67525-7

The original version of the book was inadvertently published with the incorrect author name "Jung-Hsinag Tsai", which has now been corrected to "Jung-Hsiang Tsai". The book has been updated with the changes.

The updated version of the book can be found at https://doi.org/10.1007/978-3-030-67525-7

(C) The Author(s), under exclusive license to Springer Nature $\mathrm{Cl}$ Switzerland AG 2021 J.-H. Tsai (ed.), Presidents, Unified Government and Legislative Control, Palgrave Studies in Presidential Politics, https://doi.org/10.1007/978-3-030-67525-7_8 